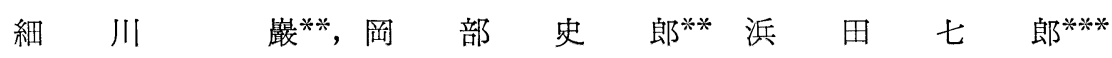

\title{
Oceanographical Studies on the Sediment in the East China Sea (I) On the Contents of Organic Carbon and Total Nitrogen
}

\author{
Iwao Hosokawa, Shiro OKaBE, Shichiro Hamada
}

\begin{abstract}
Distributions of the organic carbon and the total nitrogen in the sediments are researched on about 80 samples in this sea. The former values lie between 0.10 to $1.93 \%$, and the latter 10 to $186 \mathrm{mg} / 100 \mathrm{~g}$. These distributions are concerned with the oceanographical conditions of this sea, especially with SHIOME lines. Relations between these values and the mud content, depth of water, and $\mathrm{C} / \mathrm{N}$ are discussed.
\end{abstract}

前報1) では東支那海底土中の泥土成分量につい て報告したが，今報では同試料につき化学的検討 を加えた結果のうち有機炭素及び全窒素含量につ いて報告する。

従来, わが国周辺の海底堆積物の研究例は必ず しも少くないが，その大部分は主として地質学的 な立場からなされたもので化学的な見地から検討 された研究例は極めて少い2. 特に東支那海底土 については化学的な研究は殆んど稀であるので3), 著者らの研究は純粋化学の各分野は勿論, 水産業 界その他の方面に寄与するところが少くないもの と思われる.

〔試料〕 1957 年 2 月以来, 西海区水産研究所, 長崎県水産試験場その他によつて採泥された東支 那海底土試料約 200 個のうち, 泥土含量のや〉多 い試料約 80 個について検討した. 採泥位置は各 種測器により正確に測定され, 水深に対しては総

*1959年 4 月28日受理.

** 福岡学芸大学 Fukuoka College of Liberal Arts, Fukuoka

*** 水産庁西海区水産研究所 Western Sea Rigional Fisheries Research Laboratry, Nagasaki
て魚探を用い，採泥測深器使用の場合は潮流に対 する補正を行つている，底土試料は採泥後ホルマ リン処理を行い, 帰港後, 実験室で風乾し, これ を $105^{\circ} \mathrm{C}$ 附近で乾燥し実験試料とした。たジし， 有機炭素の定量には, 上述の実験試料を篩別し 100 メッシュを通過した部分を乾燥して実験に供 した.

\section{〔分析法〕}

1) 有機炭素定量法 小山法年によつた. 即ち, 予め酸で処理して炭酸塩を除いた試料について, 硫酸及び重クロム酸カリ等により炭素を炭酸ガス としてバリタ水に吸収させ，未反応のバリタ水を 塩酸で逆滴定する. 別に空実験を行つて, 両者の 数値の差から試料中の有機炭素を算定した.

2) 全窒素定量法 通常の Kjeldahl 法によつ た。

〔実験結果及び考察】

1）有機炭素量 第 1 四に東支那海底土の有機 炭素含量の分布を示した. 同図から明らかなよう に, 有機炭素の分布は潮目と関連をもち, 潮目附 近ではその含量に変化がみられる（潮目について 


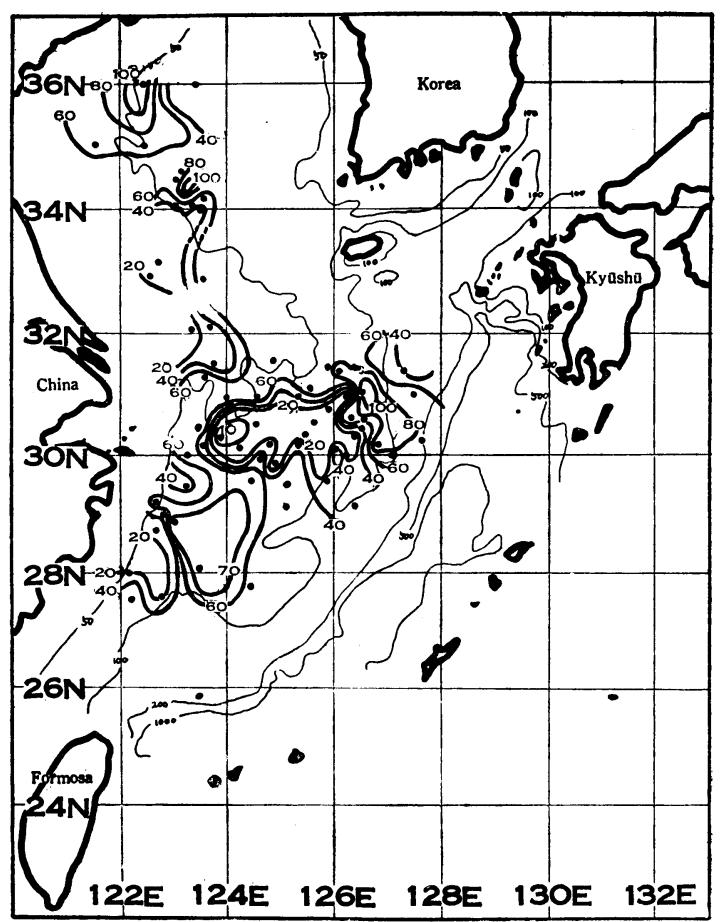

Fig. 1. Distribution of the organic carbon $(\mathrm{mg} / \mathrm{g} \times 10)$. は前報1)参照).

前報で報告したようにこれらの潮目附近では 泥土含量に極めて大さな変動がみられ，泥土含量 $20 \%$ 以下の砂質底土と泥土含量 $80 \%$ 以上の泥質底 土の水域がごく接近して存在している. これらの 底質のうち，泥土に乏しく砂質にとむ水域では有 機炭素が少なく，泥土にとんだ泥質の水域では， 反対に，有機炭素が多くなる（泥土分布について は前報 ${ }^{1)}$ 参照)．この事実は, 第 2 図の泥土含量と

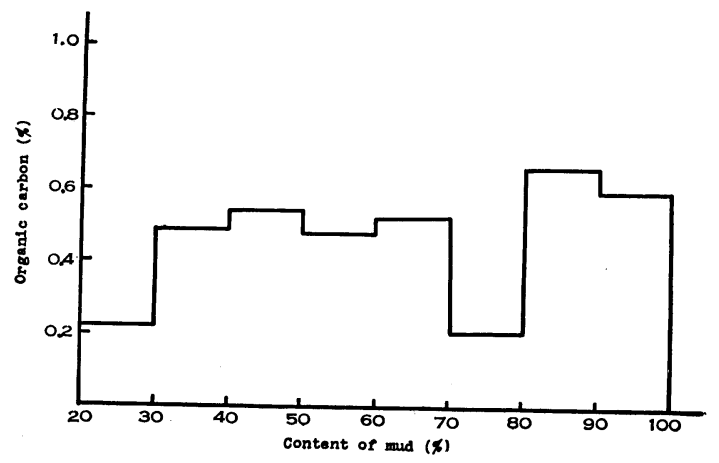

Fig. 2. Relation between organic carbon and mud in sediments.
有機炭素含量の関係を示すヒストグラムからも窺 えることで, 同図から明らかなように, 泥土量 $30 \%$ 以下では有機炭素量は著しく小であるのに対し， 泥土量 $80 \%$ 以上ではその約 3 倍の大きな值を示し ている.

又, 水深 $100 \mathrm{~m}$ 以下の水域について有機炭素量 と水深の関係をしらべると第 3 図の通りである. 即ち, 始めは水深の増加と共に有機炭素量も漸次 増加し 70〜80 m 附近で最高值に達するが，更に 水深を増すと急激な減少を示す。この傾向は，前

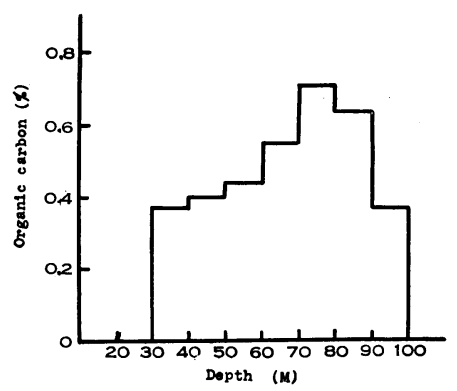

Fig. 3. Relation between organic carbon and depth.

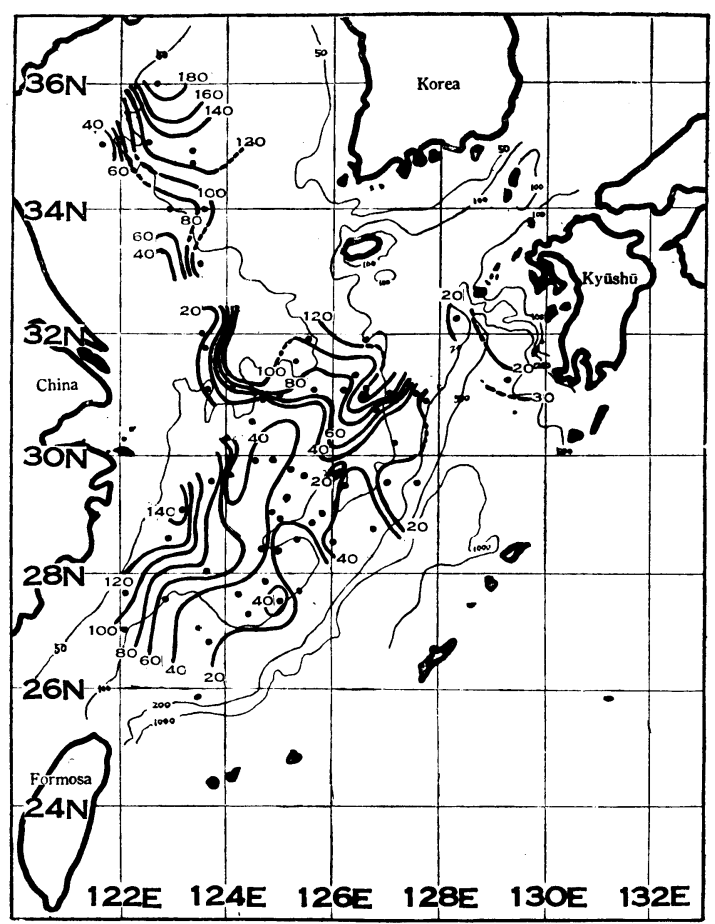

Fig. 4. Distribution of the total nitrogen (mg/100g) 
報の泥土含量と水深との関係とよく類似してお り，有機物が泥土の堆積に伴つて沈積することを あらわしているものと推定される。

2）全窒素量 第 4 図に全窒素量の分布を示し た.この分布は前述の有機炭素の場合にかなり類 似しており, 潮目附近で大きな変動をみせている。

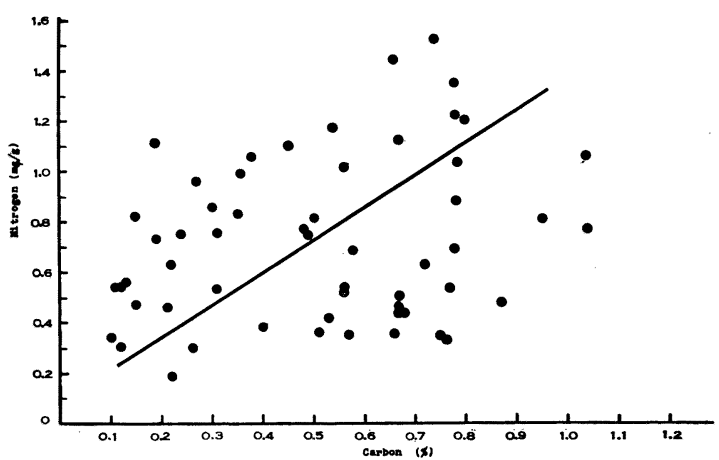

Fig. 5. Organic carbon to total nitrogen.

今有機炭素量と全窒素量の関係を第 5 図に図示す ると，両者の間にはかなり比例的な関係がみられ るので，このため両者の分布が上記の通り類似性 をもつものと思われる. この傾向は全窒素量と水 深との関係に沶いてもみられ，第 6 図の通り，水 深 $120 \mathrm{~m}$ 以下の水域では全窒素量は水深と共に増 加して 70〜80 m で最大值を示し, 更に水深が増 すと滅少しているが，これは有機炭素の場合とほ ぶ同様である.

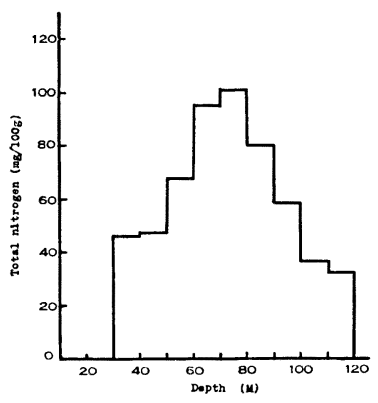

Fig. 6. Relation between total nitrogen in sediments and depth of of water.

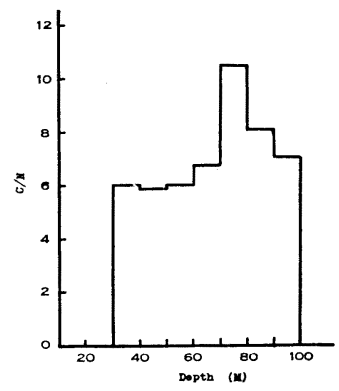

Fig. 7. Relation between $\mathrm{C} / \mathrm{N}$ and depth of water.
3） $\mathrm{C} / \mathrm{N}$ の值 $\mathrm{C}_{/}^{\prime} \mathrm{N}$ の值は，有機炭素に於ては 100 ×ッシュ以下の粒度についての分析值, 全窒素
ではそのま〉の試料についての分析值から算出し たものである. $\mathrm{C} / \mathrm{N}$ は有機炭素及び窒素の分布か ら明らかなように，潮目附近で大きな変動をみせ ている.これらは, いづれも, 異つた水系の混合 水域では著しい物理化学的及び生化学的变化がお こることを示すものであろう． C $/ \mathrm{N}$ と水深の関係 は第 7 図の通りである。即ち，水深 $30 \sim 60 \mathrm{~m}$ で は $\mathrm{C} / \mathrm{N}$ は汪とんぞ同一值を示しているが, 70〜 $\varepsilon 0 \mathrm{~m}$ では大きな値となり，更に水深を増すと減

- 少する。これは上述の関係から直ちに推測できる よ5に, $\mathrm{C} / \mathrm{N}$ の值が有機炭素量とほぶ比例的関係 になるため， $\mathrm{C} / \mathrm{N}$ と水深との関係は有機炭素と水 深の関係と類似し上述のような傾向を示すものと 認められる。

上記の実験結果の詳細は第 1 表に示した通りで ある。

以上を要約すると

1）有機炭素量, 全窒素量及び $\mathrm{C} / \mathrm{N}$ はいら゙れ も潮目附近で著しく変動する。

2) 有機炭素量と全窒素量及び $\mathrm{C} / \mathrm{N}$ の間には 夫々比例的関係が成立する.

3) 有機炭素量, 全窒素量及び $\mathrm{C} / \mathrm{N}$ はいづれ も水深 70〜80 $\mathrm{m}$ のところで最高值を示す.

終りに，東支邦海の海況その他につき御指導を 頂いた長崎海洋気象台加藤威夫技官に厚く感謝す る. 又, 底土試料の採集について御援助頂いた西 海区水産研究所, 長崎県水産試験場調査員各位に 深謝する。

$\begin{array}{cc}\text { (昭和 } 33 \text { 年 } 10 \text { 月 } & \text { 日本化学会秋季研究發表会 }(1 \text { 部) } \\ 34 \text { 年 } 4 \text { 月 } & \text { 日本海洋学会年会で登表 }\end{array}$ 文献

1) 浜田, 細川 (1959) : 東支那海底土の泥土成分につい て, 本誌 15 No. 2 (1959)

2) 例えば浜口, 他 (1954)：日本海底土の化学組成：日 本化学雑誌 74,761 (その他)

K. KATO (1956) : Chemical Investigations on Marine Humas in Bottom Sediments. Memo. Facul. Fish, Hokkaido Unive. 4, No. 2

新野 (1958)：大陸棚漁場底質の有機炭素分布（日本 海洋学会年会講演)

3) 例えば EMERY, K. O. \& NIINO, H (1957) :Sediments of Shallow Portions of East China Sea and South Chi::a Sea (第 9 回太平洋学 術会議報告)

4) Koyama, T. : J. Earth Sci. Nagoya Univ. 2, 5-14 (195؛) 


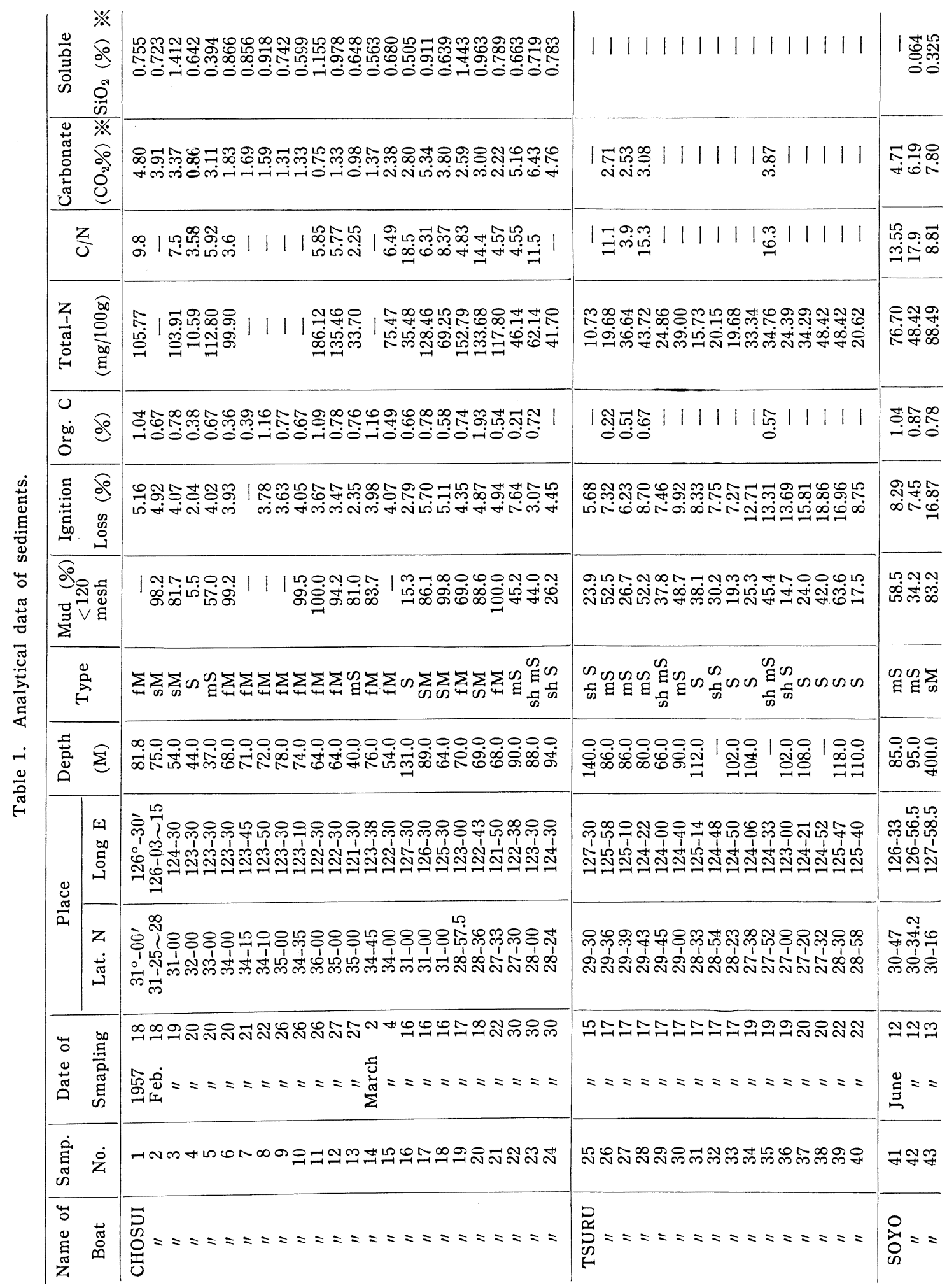




\begin{tabular}{|c|c|c|c|}
\hline 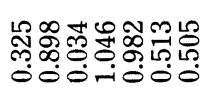 & 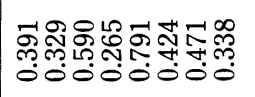 & 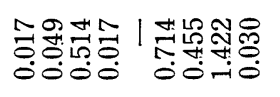 & 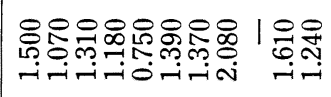 \\
\hline 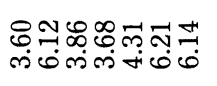 & 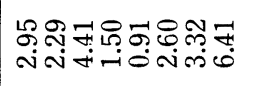 & 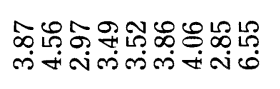 & 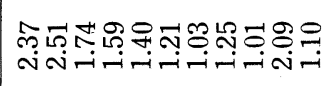 \\
\hline 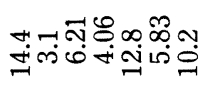 & 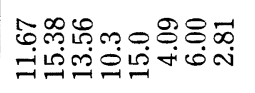 & 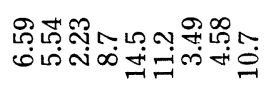 & 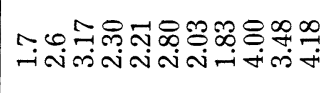 \\
\hline 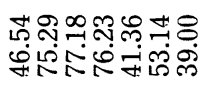 & 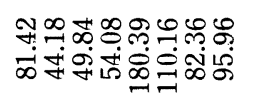 & 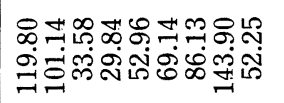 & 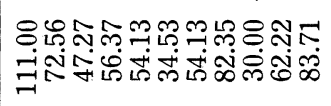 \\
\hline 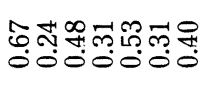 & 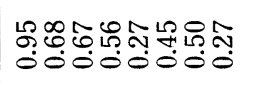 & 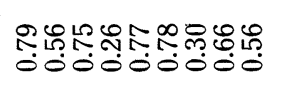 & 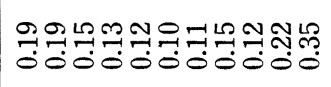 \\
\hline 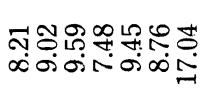 & 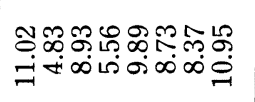 & 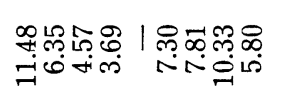 & 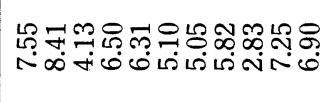 \\
\hline 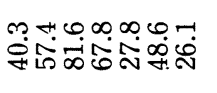 & 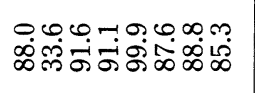 & 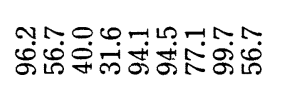 & 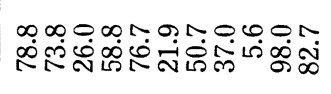 \\
\hline 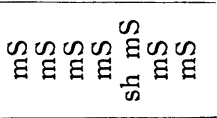 & $\sum_{i} \sum_{g} \sum_{\infty} \sum_{\infty} \sum_{i} \sum_{n} \sum_{g} \sum_{\infty}$ & 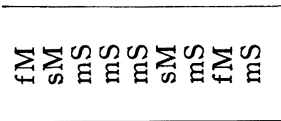 & 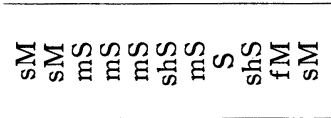 \\
\hline 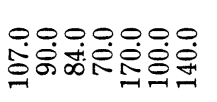 & 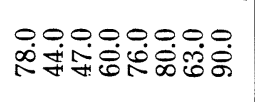 & 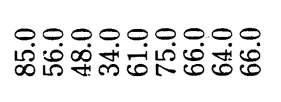 & 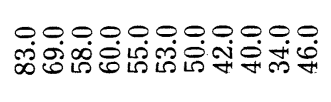 \\
\hline 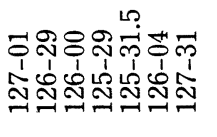 & 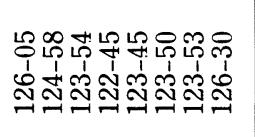 & 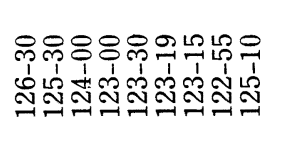 & 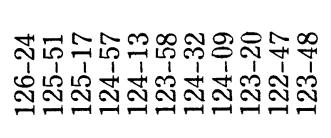 \\
\hline 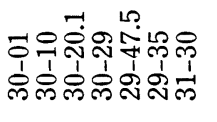 & 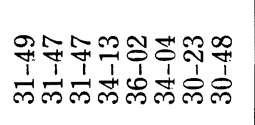 & 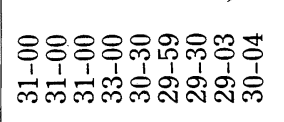 & 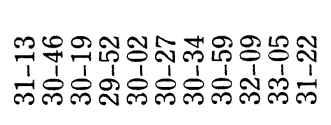 \\
\hline 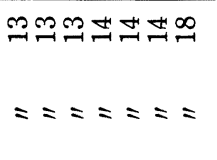 & 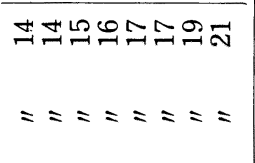 & 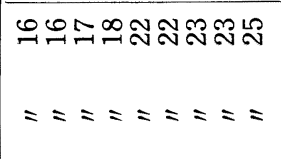 & 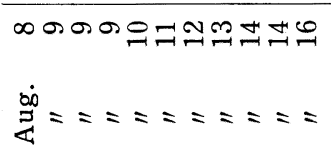 \\
\hline 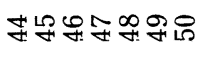 & 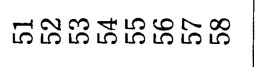 & 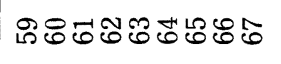 & 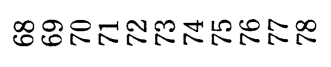 \\
\hline$===s$ & $==s=s$ & 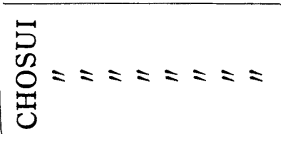 & 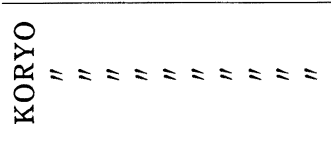 \\
\hline
\end{tabular}

